\title{
Difficulties Confronted by Higher Secondary School Students in Mizoram
}

\author{
Lallianvungi ${ }^{1}$, Ringngheti Khenglawt ${ }^{2}$ and Lallianzuali Fanai ${ }^{3 *}$ \\ ${ }^{1}$ Lecturer, Govt. K.M. Higher Secondary School, Aizawl, Mizoram, India \\ ${ }^{2}$ Christ University, Bangalore, Karnataka, India \\ ${ }^{3}$ Professor, Institute of Advanced Studies in Education, India \\ "Corresponding author: dr.zuali@gmail.com
}

Received: 18 Jul., 2019

Revised: 22 Oct., 2019

Accepted: 25 Nov., 2019

\begin{abstract}
The study conducted in Mamit District tries to find out the difficulties confronted by the students of higher secondary schools covering four (4) dimensions viz. Health, Language, Personal and Social. It was found out that most of the students are free from tensions and worries in relation to their difficulties. 86.47 percentage of the subjects could not express their feelings and ideas in English. 69 percentage agreed that they could not follow when teachers speak fast in class. 16.4 percentage were facing difficulty due to active involvement in church activities. 33.1 percentage of the learners lack self-confidence. $38.1 \%$ claimed that no support or assistance had been obtained from friends in their learning. $16.4 \%$ of the subject agreed that involvement and participation in church activities caused distractions to their learning. Teachers should try to adjust their speed according to the level and pace of the learners and at the same time ensure that the students are able to keep up with the teaching activity. Request the parents to spare more time for their children's learning and give more cooperation in their studies will bring fruitful results in students' learning.
\end{abstract}

Keywords: Difficulties confronted, health, language, personal and social

According to Education Commission (1964-1966), which is also known as Kothari Commission, "If this change on a grand scale is to be achieved without violent revolution (and even then it would still be necessary) there is one instrument only, that can be used "Education". Other agencies may help and can indeed sometimes have a more apparent impact. But the national system of Education is the people. It is not, however, a magic word to wave wishes into existence. It is a difficult instrument, whose effective use requires strength of will, dedicated work and sacrifice. But, it is a sure and tried instrument, which has served other countries well in their struggle for development. It can give the will and the skill, do so for India.

\section{Mamit District- The Study Setting}

The present study undertaken in Mamit District is situated in the western part of Mizoram. It came into being as a district in the year 1997 with Mamit as its capital town. As per 2011 Census report, the percentage of literacy rate in the district is $85.96 \%$. There are four (4) Higher Secondary Schools in the district with 230 students and thirty four (34) number of teachers.

The first high school in Mamit District was

How to cite this article: Lallianvungi, Khenglawt, R. and Fanai, L. (2019). Difficulties Confronted by Higher Secondary School Students in Mizoram. Int. J. Peace, Edu. and Deve., 7(02): 109-113.

Source of Support: None; Conflict of Interest: None (ㅇ) क्ष 
established at Kawrthah in the year 1956 and its first Headmaster was George L. Chawngthu (L). This school was upgraded into higher secondary school in 1996, the time when Mizoram has introduced the ten plus two $(10+2)$ system.

Teaching- learning process is influenced by the totality of the situation. Teaching learning is related to the life situations. Teachers can play an important role in facilitating learning when they take into account the needs of the learners. A learner needs the help of a teacher when he wants to learn any subject and to solve any problem (J.C. Aggarwal, 2007).

Miss Grace Owing, a pioneer in the field of early childhood education there are seven objectives of pre-primary schools. These are as follows: To provide healthy environment to the children like space, fresh air, light and sun shine, to provide a healthy, happy and regular life, to provide continuous medical supervision, to assist in the formation of healthy, to give opportunity for the development of different interests and skills of various kinds, to establish real unity between external environment and home life" (Jagannath Mohanty, Bhagyadhar Mohanty, 2002).

The learning process and teaching method need a new orientation from the Nursery level to the highest level. Greece used dialogues and debates as a part of the total system of education. The Chinese had examinations for selection of their civil servants as early as 200 B.C. Amrit (LalVohra, Shita Ram Sharma, 1990).

Today, as never before, India, needs educational institutions not only to guard its past but also to advance its future. "The destiny of India is now being shaped in the class-rooms". This is the assessment of situation by the first ever comprehensive commission (1964-66) on Indian Education, schools are to be the first class nurseries for the education of children in democratic citizenship which India needs to make its democracy permanently viable, efficient school administration is crucial to the success of democracy, some theory and philosophy will have to be evolved for guiding the educational administration process at all levels and to be clear about the objective so that we do not miss the target (S.K. Kochhar, 1970).

Academic performance of the major indicator of an individual's potential, expertise and success is not an independent phenomenon, rather it is influenced by a number of factors, some of which are personal to the individual while many others are located in the environment in which the learning takes place i.e. school and family. Home environment and other family characteristics constitute one of the most important factors that determined the lead of achievement of a child in school (Havighurot, 1963).

Parents can contribute in diverse ways towards development outcomes of their children. More direct ways through which parent can influence academic performance of the children is through cognitive stimulation (Taruna C. Dhall, Madhu Sahni, 2008).

Academic adjustment involves students healthy adjustment to school or college environment. The class room teacher plays the most strategic role in ameliorating the environment to bring about an improved adjustment of pupil. Raymond N. Hatch and Buford Stifle describe the role of the class room teacher in providing a healthy environment as one that would complement the adjustment process of each pupil.

There is a close Relationship between adjustment and education. Well adjusted individuals proper well in their educational Endeavour. Those who have adjustment problems in schools and college will be related in their scholastic progress. Hence, teacher should ensure that their students adjust well to the academic environment of the school (Najma Unnisa, 2011).

\section{Statement of the Problem}

'A study of Difficulties Confronted by Higher Secondary School Students in Mizoram".

\section{Objective of the Study}

$\odot$ To identify the difficulties confronted by students of Higher Secondary Schools in Mizoram with respect to Health, Language, Personal and Social dimensions. 


\section{Methodology and Procedure}

In the present study descriptive method of research is used. It involves gathering data that describe events and then organizes, tabulates, depicts, and describes the data collection.

\section{Population and Sample}

The population of the study comprised of all the students of Higher Secondary Schools in Mizoram. For the sample of the study, students from all higher secondary schools at Mamit District were selected.

\section{Tool Employed}

A problem Check-list prepared by the investigator was used for studying the four (4) areas: (1) Health; (2) Language; (3) Personal; (4) Social.

\section{Mode of Data Collection}

Permission was taken from all the Principals of the Higher Secondary Schools in Mamit District. Developed good rapport and thereby administered the questionnaires to all students of Higher Secondary Schools in Mamit District, Mizoram.

\section{Data analysis and Interpretation of the study}

The data obtained from the Four Higher Secondary Schools were analysed on the basis of the responses given by the school students using the indices Agree, Disagree and Undecided in the questionnaire. The number of responses for each variable taken in raw scores were converted into percentages for establishing their relation to the learning environment. The obtained results were shown in the following tables:

Table 1: Problems of Health

\begin{tabular}{|c|c|c|c|c|}
\hline $\begin{array}{l}\text { Sl. } \\
\text { No. }\end{array}$ & Particulars & Agree & Disagree & Undecided \\
\hline 1 & Health problems & $28.9 \%$ & $63.2 \%$ & $7.7 \%$ \\
\hline 2 & $\begin{array}{l}\text { Health of family } \\
\text { members }\end{array}$ & $13.5 \%$ & $74.8 \%$ & $11.5 \%$ \\
\hline 3 & Vision problems & $26 \%$ & $66.1 \%$ & $7.7 \%$ \\
\hline 4 & Hearing problems & $8.6 \%$ & $88.4 \%$ & $2.8 \%$ \\
\hline
\end{tabular}

63.2 percent claimed that the health of their family members had no visible effects on their studies. $74.8 \%$ did not face vision and hearing problem which could affect their learning.

Table 2: Problem with Language Usage

\begin{tabular}{ccccc}
\hline $\begin{array}{c}\text { S1. } \\
\text { No. }\end{array}$ & Particulars & Agree & Disagree & Undecided \\
\hline 1 & Ability of self & $86.47 \%$ & $10.4 \%$ & $3.13 \%$ \\
2 & $\begin{array}{c}\text { expression } \\
\text { Study of Mizo } \\
\text { vernacular }\end{array}$ & $74.3 \%$ & $14 \%$ & $11.59 \%$ \\
3 & $\begin{array}{c}\text { Modulation of voice } \\
\text { (speed and clarity) }\end{array}$ & $69 \%$ & $23.1 \%$ & $7.7 \%$ \\
4 & Writing ability & $24.6 \%$ & $63.7 \%$ & $11.5 \%$ \\
\hline
\end{tabular}

86.47 percentage of students said that they could not express their feelings/ideas in English. 69 percentage of subjects agreed that they could not follow the teacher's teaching because of the fast speed.

Table 3: Personal Problems

\begin{tabular}{ccccc}
\hline $\begin{array}{c}\text { S1. } \\
\text { No. }\end{array}$ & Particulars & Agree & Disagree & Undecided \\
\hline 1 & Self- confidence of & $33.1 \%$ & $53.1 \%$ & $13 \%$ \\
& students & & & \\
2 & Physical factors & $11.1 \%$ & $70 \%$ & $18.8 \%$ \\
3 & $\begin{array}{c}\text { Assistance received } \\
\text { in studies }\end{array}$ & $38.1 \%$ & $51.6 \%$ & $10.1 \%$ \\
\hline
\end{tabular}

33.1percentage of the learners lack self- confidence. $38.1 \%$ claimed that no support or assistance had been received from friends in their learning.

Table 4: Social problems

\begin{tabular}{ccccc}
\hline $\begin{array}{c}\text { S1. } \\
\text { No. }\end{array}$ & Particulars & Agree & Disagree & Undecided \\
\hline 1 & $\begin{array}{c}\text { Disturbance caused } \\
\text { by local politics }\end{array}$ & $6.2 \%$ & $86.4 \%$ & $7.2 \%$ \\
2 & $\begin{array}{c}\text { Involvement in } \\
\text { community Activities } \\
\text { Disturbance caused } \\
\text { by local factors }\end{array}$ & $12.5 \%$ & $70.5 \%$ & $16.9 \%$ \\
4 & $\begin{array}{c}\text { Involvement in } \\
\text { church Activities }\end{array}$ & $16.4 \%$ & $75.3 \%$ & $8.2 \%$ \\
5 & $\begin{array}{c}\text { Distractions caused } \\
\text { by friends }\end{array}$ & $18.3 \%$ & $72.9 \%$ & $8.6 \%$ \\
6 & $\begin{array}{c}\text { Hostility and quarrel } \\
\text { affect study }\end{array}$ & $15.9 \%$ & $75.3 \%$ & $86.1 \%$ \\
\hline
\end{tabular}


$16.4 \%$ of the subject agreed that involvement and participation in church activities caused distractions to their learning. 18.3 percentage faced disturbance from their friends. $15.9 \%$ students were affected by conflicts in their neighbourhood.

\section{Major Findings}

$\odot 63.25 \%$ of the subjects had sound health of family members, $66.1 \%$ learners were free from eye sight problems and $88.4 \%$ had sound hearing system. Generally, students have sound health.

$\odot 86.47 \%$ learners could not express their feelings and ideas in English.

$\odot 53.1 \%$ of students had self confidence, $70 \%$ had not bothered with their physical appearance and $51.6 \%$ learners had good companion to help in studies.

$\odot$ Only a few subjects $16.4 \%$ of the subject agreed that involvement and participation in church activities caused distractions to their learning.18.3 percentage faced disturbance from their friends. $15.9 \%$ students were affected by conflicts in their neighbourhood. Therefore, most of the students had congenial environment for their studies.

\section{Recommendations}

$\odot$ Telling the students to take care of their health by keeping personal health and hygiene and consulting the medical experts instantly when they had ill-health.

$\odot$ It is necessary to practice the English language in the classroom as well as in the school premises in order to get exposure in the language.

$\odot$ Teachers should try to adjust their speed according to the level and pace of the learners and at the same time ensure that the students are able to keep up with the teaching activity.

$\odot$ Request the parents to spare more time for their children's learning and give more cooperation in their studies and restrict their child not to involve in community and church activities during study.

\section{Limitations of the study}

The present study covers only the higher secondary school students. Besides, some students were absent on the date of administering the test. It is desirable that all students could be present during the test to get a wider and more extensive results.

\section{CONCLUSION}

From the data obtained, the major issue lies in English language usage as students could not express in English what they want to reveal. This creates tensions in their learning as all subjects except for one (1) vernacular language are all English medium. Besides, some students are too much involve in the church and community activities which hinders their study growth.

\section{REFERENCES}

Aggarwal, J.C. 1971. "The progress of Education in Free India". Arya Book Depot. New Delhi.

Aggarwal, J.C. 2007. "Principles, Methods and Techniques of Teaching", pp. 55,55.

Albert, J Rensa Jr: School in a changing society. The Free Press, Collier. Mac Millan Ltd., London, New York.

Anand, C.L. 1975. Role of Education in the process of Modernization. Teacher Today, XVIII(2).

Anderson, R.H. 1966. Teaching is a world of change. Harcout Brave of world. Inc. USS.

Bakshi, G.L. 1977. Towards Better Education, Chord and Co. Ltd. New Delhi.

Dhall Tarun C. and Madhu Sahni Dr., "Academic performance of Elementary School Children of working and non-working mothers", pp. 14.

Dhawan, M.L. 2005. "Learners with Special Needs", pp. 2-4.

Goswami, S.P. Kinship system of the Lushai. Bulletin of the Anthropological Survey of India, 9(2).

Hawla, V. Mizo Hnam Chanchin. Zosaptechanchin (1897-1968) Synod publication Board.

Hemchand, T.K., "Problems of Secondary Education", pp. 137140.

Hrangtiauva 1976. History and Culture of the Mizo's, Mizochanchin. Lalrinliana \& Sons, Bara Bazar, Aizawl.

http//kidshealth.org/kid/health problems/learning problems /learning disabilities.html/

Jagannath Mohanty and Bhagyadhar Mohanty. 2002. “Early Childhood Care and Education (ECCE), pp. 4-7. 
Jahitha Begum and Vakkil M. "Managing Specific learning disabilities-Role of teachers", pp. 136-140.

Kochhar, S.K. 1970. "School Secondary Administration”, pp. 6,7.

Lalbiakliana. 1981. Mizo Zirna Chanchin, Social Education wing. Education Department, Mizoram; Aizawl.

Nghaklianmawia. 2004. Mamit District Khaw Hranghrang Chanchin'.

Parijit Kotwal. 2008. "Special Education", pp. 1.

Prem Kumar Jha, “Learning Disabilities”, pp. 54.

Ralte Lalliani Dr. "Special Education for the Exceptional Children", pp. 14.
Rashmi Agrawal, and Rao, BVLN. “Learning Disabilities, Teaching Learning Strategies".

Singh, R.P. 1976. Indian Education Review. A Research Journal, XI(3).

Statistical hand book, Mizoram, 1985.

Statistical Hand book of Mizoram, 2011.

Thanga, L.B. 1975. "The Mizos, A Study in racial Personality", United Publishers, Gauhati, pp. 5. 
